\title{
Leaf and root evaluation of bioactive compounds of different beetroot varieties
}

\author{
Tímea Rubóczki - Mária Takácsné Hájos \\ University of Debrecen, Faculty of Agricultural and Food Sciences and Environmental Management, \\ Institute of Horticultural Science, Debrecen \\ ruboczkit@agr.unideb.hu
}

\begin{abstract}
SUMMARY
The importance of beetroot lies in the numerous health benefits, attributed to its wide-ranging array of minerals, vitamins and bioactive compounds which play a key role in the human diet. Generally, beetroot is consumed for its root, however, its leaves also contain a good amount of bioactive compounds. The experiment was carried out with four beetroot varieties in order to compare the amount of bioactive compounds in the root and the leaf. The analyzed data were total dry matter content, total polyphenol, flavonoid and vitamin $C$.

Results have shown that roots contain the highest amount of bioactive compounds. Nevertheless, leaves can be also considered a significant source. Therefore, consumption of the young leaves is highly recommended due to their availability after thinning or at maturity stage (60 days after the germination). Of the examined varieties, 'Libero' demonstrated the highest total polyphenol, flavonoid and vitamin $C$ values, although it was found to be statistically insignificant.
\end{abstract}

Keywords: beetroot variety, beetroot leaf, bioactive compounds, second cultivation

\section{INTRODUCTION}

Beetroot (Beta vulgaris ssp. esculenta var. rubra L.) is a member of the Chenopodiaceae family. It is a root vegetable which is mainly cultivated throughout Europe, America and Asia. Particularly in Europe and North America, it is more widely used as fresh, salads, components of soups and desserts.

In Hungary, beetroot is generally sown as a second crop (end of June, beginning of July) because of the short growing period (100-110 days) and autumn processing capacity (Takács-Hájos and Rubóczki 2012). Unfortunately, the growing area is not even 400 hectares which is approx. $0.3 \%$ of the total vegetable area. With regard to its consumption, increasing interest has been shown in the last decade and nowadays the market offers beetroot with the leaves together for fresh consumption. In addition, the young plants, which are generally thinned by hand are good to eat as young leaves (its taste resembles of spinach).

The importance of beetroot lies in the numerous health benefits, attributed to its wide-ranging array of minerals, vitamins and bioactive compounds which play a key role in the human diet (Petek et al. 2012). For instance, Neelwarne (2013) reported several properties against inflammation, tumors, microorganisms, mutagenicity along with protection from cardiovascular disease and free radical-scavenging abilities (Ninfali and Angelino 2013).

Of the bioactive compounds found in beetroot, the most important ones are polyphenols, flavonoids, betalains and ascorbic acid (vitamin $\mathrm{C}$ ). Together are responsible to provide specific properties that beetroots bring about.

Polyphenols and flavonoids inhibit the harmful effects of oxidative degradation among macromolecules such as proteins, lipids and DNA. Concerning to betalains, they have demonstrated antiradical, antioxidant and anti-inflammatory activities. In fact, when human lowdensity lipoproteins are enriched with betalains, they effectively increase the resistance to oxidation (Slavov et al. 2013).

Furthermore, their use as natural colorants by the food industry is being broadened (ZielinskaPrzyjemska et al. 2009, Georgiev et al. 2010, Wruss et al. 2015). Finally, vitamin $C$ is an antioxidant that protects human body from free radical damages, thriving in its role of regulating metabolic functions such as the activation of the vitamin B and folic acid (Iqbal et al. 2004).

A point to remark is the sensitivity that vitamin C and phenolic compounds hold. They are, to varying degrees, water-soluble, thermally labile and sensitive to oxidation. All these properties make them more delicate to degradation during processing, storage and cooking than other nutrients (Rickman et al. 2007)

\section{MATERIAL AND METHODS}

The experiment was carried out at the University of Debrecen, Farm and Regional Research Institute in its Botanical and Exhibition Garden with the following varieties: 'Bonel', 'Libero', 'Larka', 'Akela'. Measurements were performed at the Agricultural Laboratory Center.

Sowing was performed at the end of June 2017 as a second cultivation. The experiment was carried out on lowland chernozem soil type and was conducted as a randomized complete block with three replications. The space between rows was $35 \mathrm{~cm}$ and parcel size was $5 \mathrm{~m} \times 0.4 \mathrm{~m}$.

The multigerm genotypes are propagated by seed (clusters holding from 3 to 5 seeds). Therefore, it is necessary to thin the beets when they are young ( 2 to 4 leaves). In this experiment the thinning was done two weeks after the germination (12 of July).

During the growing season, the soil was loosened in order to enable proper root development. The plants were protected against flea and fungal disease as usual for beets. 
Sampling was done after two months of germination (29 of August). At this stage it is still possible to consume the leaves (Figure 1).

Figure 1: Sampled beetroot varieties (Debrecen, 2017)
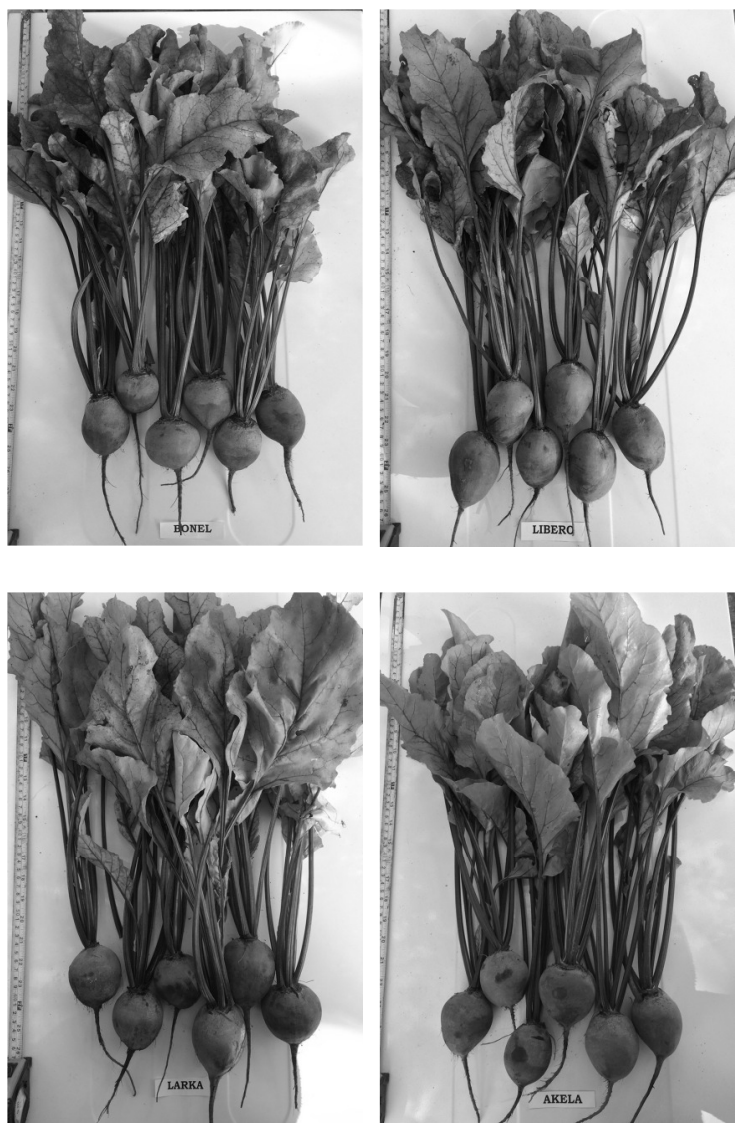

The properties of the evaluated varieties:

- 'Bonel': Excellent variety for early (March/April) sowing, uniform smooth roots with excellent colour for processing. Medium short, upright, leaf habit for easier harvesting.

- 'Libero': Multigerm, fast growing genotype with smooth surface and intense inner colour.
- 'Larka': It can be cultivated around the year. It produces round and uniformly colored roots.

- 'Akela': Multigerm, round variety with intense dark red colour. It displays high cold tolerance and is slow to bolt. It can be sown early and late in the season. The foliage is strong and healthy. It offers good storability, and high yields for processing.

The main object of this work was to evaluate and to compare the bioactive compounds as dry matter, polyphenols, flavonoids and vitamin $\mathrm{C}$ of the beet in the root and in the leaf when they are consumable.

After sampling, the following parameters were evaluated in laboratory (expressed in fresh weight):

- Total dry matter content (\%) - drying on $105{ }^{\circ} \mathrm{C}$,

- Total polyphenol content expressed in Gallic Acid Equivalents (GAE); (mg GAE $100 \mathrm{~g}^{-1}$ ) - FolinCiocalteu colorimetric method (Singleton et al. 1999),

- Flavonoid content expressed in Catechin Equivalents (CE); (mg CE $100 \mathrm{~g}^{-1}$ ) - colorimetric method described by Lamaison and Carnat (1990),

- Vitamin C content (mg $100 \mathrm{~g}^{-1}$ fresh weight) measured by MSZ ISO 6557-2:1991 protocol.

\section{RESULTS AND DISCUSSION}

\section{Total dry matter content}

In addition to sugar, other components as dietary fibres are part of the total dry matter content. Its values are determined by the variety and climatic effects during the vegetation period.

Analyzed data of total dry matter content are presented in Figure 2.

Total dry matter in the roots $(26.10 \%)$ was definitely presented in higher amounts compared to the leaf values $(9.04 \%)$. Takács-Hájos et al. (2004) have detected lower amounts in 'Bonel' $(7.83 \%)$ and 'Libero' $(8.50 \%)$ after harvesting. Furthermore, Takács-Hájos and Rubóczki (2012) have analyzed different amounts in 'Libero' (9.78\%), 'Larka' (10.34\%), 'Akela' (12.27\%) and 'Bonel' (12.49\%).

Figure 2: Total dry matter content (\%)

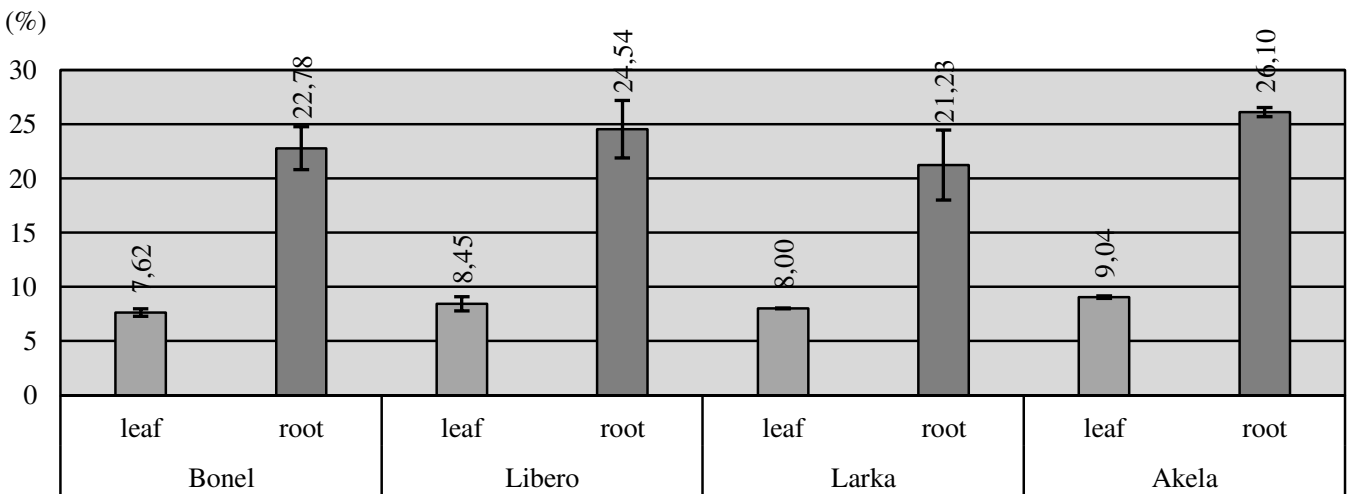

Variety per part of the beet 


\section{Total polyphenol and flavonoid content}

Polyphenols including flavonoids are one of the most important bioactive compounds due to their numerous positive effects on the human body. Previous studies have stated that beetroot is rich in these phenolic compounds not only in the roots but also in the leaves (Ninfali and Angelino 2013). The same researchers have found that the highest phenolic content in Swiss chard leaves (close genetic relation with beetroot) was measured 55-65 days after germination. Therefore, the maximum phenolic intake is reached by harvesting the leaves at the maturity stage (60 days after germination).

Measurements of total polyphenol and flavonoid are shown in Figure 3 and Figure 4.

Higher amount of polyphenols were found in the roots (Figure 3), however, these quantities are closely followed by the amounts measured in the leaves. The flavonoid content showed a similar trend (Figure 4). The highest total polyphenol content was found in 'Libero' (210.25 mg GAE $100 \mathrm{~g}^{-1}$ ), although it was found to be statistically insignificant (Figure 3).

Researchers have observed even higher values as $255 \pm 48 \mathrm{mg}$ GAE $100 \mathrm{~g}^{-1}$ (Guldiken et al. 2016) and $305.5 \pm 6.08 \mathrm{mg}$ GAE $100 \mathrm{~g}^{-1}$ (Farcas et al. 2012) in beetroot.

Similarly, no statistical differences were found in the flavonoid content, except in the case of 'Akela' (18.59 mg CE $100 \mathrm{~g}^{-1}$ ) and 'Larka' (13.31 mg CE 100 $\left.\mathrm{g}^{-1}\right)$ (Figure 4).

Previous experiment with the varieties ('Bonel', 'Libero', 'Larka', 'Akela') showed lower total polyphenol content (64.87-83.37 mg GAE $\left.100 \mathrm{~g}^{-1}\right)$, but similar flavonoid content (15.77-22.73 mg CE $100 \mathrm{~g}^{-1}$ ) in the root after harvesting (100 days after germination) (Rubóczki et al. 2015).

Figure 3: Total polyphenol content of varieties in root and leaf

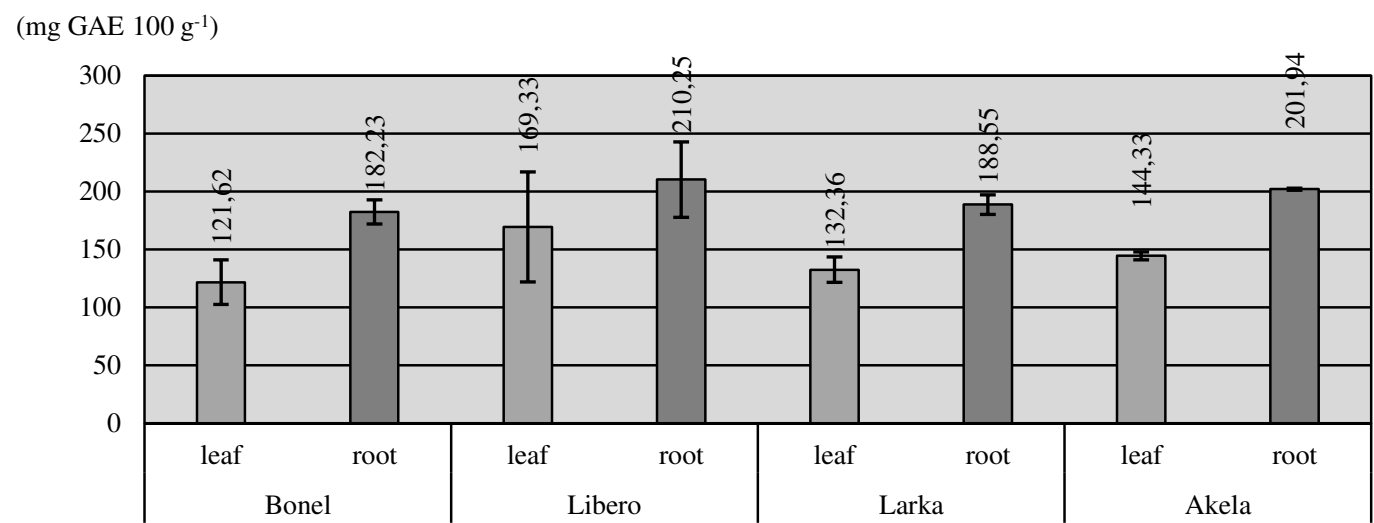

Variety per part of the beet

Figure 4: Flavonoid content of varieties in root and leaf

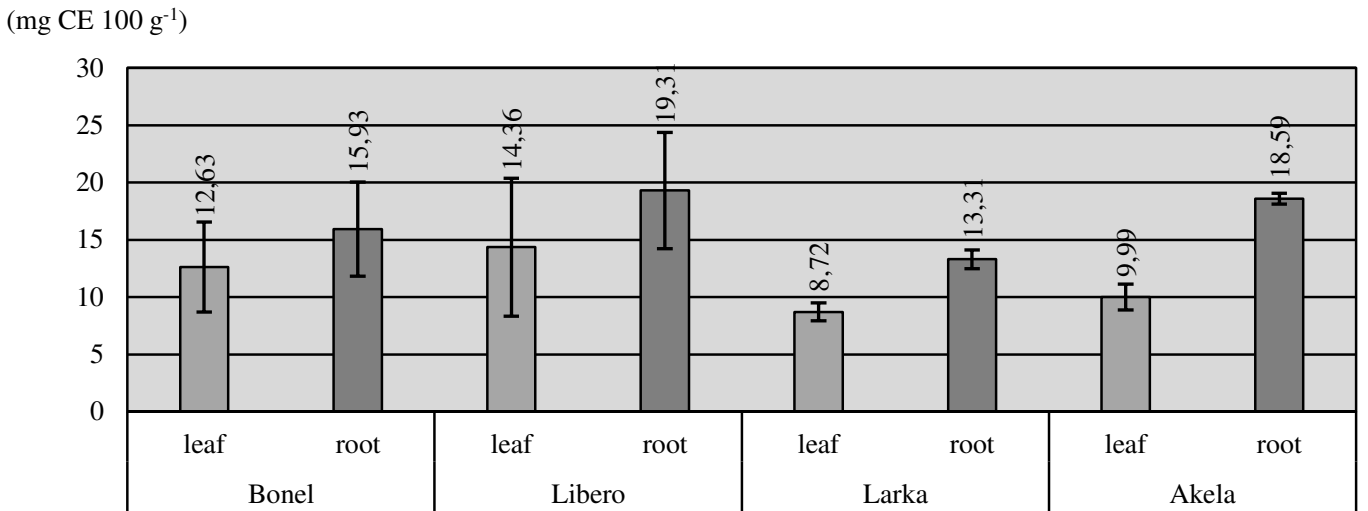

Variety per part of the beet 


\section{Vitamin $C$ content}

Ascorbic acid is by far the least stable nutrient, it is highly sensitive to oxidation. Retention of nutrients is highly dependent on cultivar, production location, maturity stage, season and processing conditions (Rickman et al. 2007).

Beetroot contains vitamin $\mathrm{C}$ in the root and in the foliage as well. Analyzed data are shown in Figure 5.

However, 'Libero' demonstrated the highest vitamin C content (16.12 mg $\left.100 \mathrm{~g}^{-1}\right)$, the data were not statistically significant. Vitamin $\mathrm{C}$ content in the leaves showed similar trend. Compared to the roots, the vitamin $\mathrm{C}$ content in the leaves were high as well. Researchers have found various data (4.9-21.66 mg $\left.100 \mathrm{~g}^{-1}\right)$ in measuring vitamin $\mathrm{C}$ content in beetroot (Nagy et al. 2015, Chawla et al. 2016). Besides, Rickman et al. (2007) analyzed similar amount of vitamin $C$ in the spinach (28.1 mg $\left.100 \mathrm{~g}^{-1}\right)$.

Figure 5: Vitamin C content of varieties in root and leaf

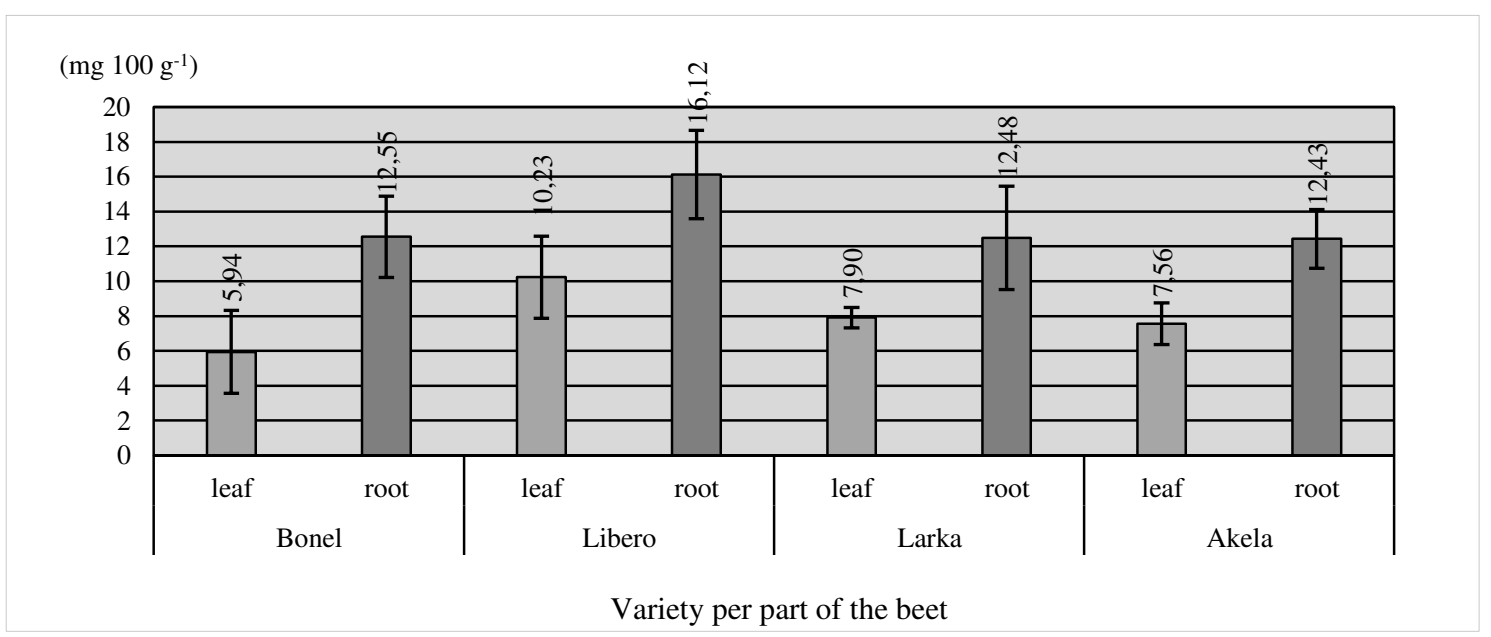

\section{CONCLUSIONS}

The experiment aimed to evaluate and to compare the bioactive compounds such as total dry matter, polyphenols, flavonoids and vitamin $\mathrm{C}$ of beetroot varieties in the root and in the leaf when they are consumable.

Results have shown that roots contain the highest amount of bioactive compounds. However, leaves can be also considered a significant source. In fact, more than $60 \%$ of the bioactive compounds found in roots were also present in the leaves.
Therefore, consumption of the young leaves is highly recommended due to their availability after thinning or at the maturity stage (60 days after the germination). Within varieties 'Libero' demonstrated the highest total polyphenol, flavonoid and vitamin C values, although it was found to be statistically insignificant.

\section{ACKNOWLEDGMENTS}

This study was supported by the ÚNKP-17-3 New National Excellence Program of the Ministry of Human Capacities.

\section{REFERENCES}

Chawla, H.-Parle, M.-Sharma, K.-Yadav, M. (2016): Beetroot: A Health Promoting Functional Food. Inventi Rapid: Nutraceuticals. 1: 1-5

Farcas, A. C.-Tofana, M.-Socaci, S. A.-Salanta, L. C.-Michiu, D.Muresan, A. (2012): Total Polyphenols from Different Fresh and Processed Fruits and Vegetables. Bulletin UASVM Agriculture. 69. 2: 262-266.

Georgiev, V. G.-Weber, J.-Kneschke, E. M.-Denev, P. N.-Bley, T.-Pavlov, A. I. (2010): Antioxidant activity and phenolic content of betalain extracts from intact plants and hairy root cultures of the red beetroot Beta vulgaris cv. Detroit dark red. Plant Foods for Human Nutrition. 65. 2: 105-111.
Guldiken, B.-Toydemir, G.-Memis, K. N.-Okur, S.-Boyacioglu, D.-Capanoglu, E. (2016): Home-Processed Red Beetroot (Beta vulgaris L.) Products: Changes in Antioxidant Properties and Bioaccessibility. International Journal of Molecular Science. 17: 858 .

Iqbal, K.-Khan, A.-Khan Khattak, M. M. A. (2004): Biological Significance of Ascorbic Acid (Vitamin C) in Human Health A Review. Pakistan Journal of Nutrition. 3. 1: 5-13.

Lamaison, L.-Carnat, A. (1990): Teneurs en acide rosmarinique, en dérivés hydroxycinnamiques totaux et activités antioxydantes chez les Apiacées, les Borraginacées et les Lamiacées médicinales. Pharm. Acta. Helv. 65: 315-320. 
Nagy A.-Jávor A.-Takácsné Hájos M.-Borbélyné Varga M.Soltész P.-Csiki Z. (2015): Céklalé készítése során fellépő beltartalmi változások, alkalmazhatósága állati eredetú funkcionális élelmiszerek fejlesztésére. Agrártudományi Közlemények. 65: 53-57.

Neelwarne, B. (2013): Red Beet Biotechnology. [In: Bhagyalakshmi Neelwarne (ed). Food and Pharmaceutical Applications.] Springer. 435.

Ninfali, P.-Angelino, D. (2013): Nutritional and functional potential of Beta vulgaris cicla and rubra. In Fitoterapia. 89: 188-199.

Petek, M.-Herak Custic, M.-Toth, N.-Slunjski, S.-Coga, L.Pavlovic, I.-Karazija, T.-Lazarevic, B.-Cvetkovic, S. (2012): Nitrogen and Crude Proteins in Beetroot (Beta vulgaris var. conditiva) under Different Fertilization Treatments. Not. Bot. Horti. Agrobo. 40. 2: 215-219.

Rickman, J. C.-Barrett, D. M.-Bruhn, C. M. (2007): Nutritional comparison of fresh, frozen and canned fruits and vegetables. Part 1. Vitamins C and B and phenolic compounds. Journal of the Science of Food and Agriculture. 87: 930-944.

Rubóczki, T.-Raczkó, V.-Takácsné Hájos, M. (2015): Evaluation of morphological parameters and bioactive compounds in different varieties of beetroot (Beta vulgaris L. ssp. esculenta GURKE var. rubra L.). International Journal of Horticultural Science. 21. 3-4: 31-35.
Singleton, V. L.-Orthofer, R.-Lamuela-Raventós, R. M. (1999): Analysis of total phenols and other oxidation substrates and antioxidants by means of folin-ciocalteu reagent. Methods in Enzymology. 299: 152-178.

Slavov, A.-Karagyozov, V.-Denev, P.-Kratchanova, M.Kratchanov, C. (2013): Antioxidant Activity of Red Beet Juices Obtained after Microwave and Thermal Pretreatments. Czech J. Food Sci.31. 2: 139-147.

Takács-Hájos, M.-Rubóczki, T. (2012): Effects of environmental factors on morphological and quality parameters of table beetroot. Journal of Horticultural Science. 18. 2: 139-146.

Takács-Hájos, M.-Varga, I. Sz.-Lugasi, A.-Fehér, M.-Bányai, É. S. (2004): Correlation between pigment contents and FRAP values in beet root (Beta vulgaris ssp. esculenta var. rubra). International Journal of Horticultural Science. 10. 4: 85-89.

Wruss, J.-Waldenberger, G.-Huemer, S.-Uygun, P.-Lanzerstorfer, P.-Müller, I.-Höglinger, O.-Weghuber, J. (2015): Compositional characteristics of commercial beetroot products and beetroot juice prepared from seven beetroot varieties grown in Upper Austria. Journal of Food Composition and Analysis. 42: 46-55.

Zielinska-Przyjemska, M.-Olejnik, A.-Dobrowolska-Zachwieja, A.-Grajek, W. (2009): In vitro effects of beetroot juice and chips on oxidative metabolism and apoptosis in neutrophils from obese individuals. Phytotherapy Research. 23. 1: 49-55. 